\title{
EFFECT OF PRECIPITATION HARDENING ON CORROSION BEHAVIOR FOR ALUMINUM ALLOYS 2024 AND 6061 IN 0.5M HCL
}

\author{
'Saraa M. Mohammed ${ }^{1}$
}

Sahib M. Mahdi ${ }^{1}$

1) Materials Engineering Department, College of Engineering, Mustansiriyah University, Baghdad, Iraq

\begin{abstract}
The corrosion behavior of both AA 2024 and AA 6061 aluminum alloys in $0.5 \mathrm{M} \mathrm{HCl}$ before and after solution treatment at room temperature $\left(25^{\circ} \mathrm{C}\right)$ was investigated in this paper to know the effect of the solution heat treatment on the corrosion behavior of both 2024 and 606 aluminum alloys. Using the cyclic polarization test, the corrosion resistance of AA 2024 aircraft aluminum alloy decreases after solution treatment at $495{ }^{\circ} \mathrm{C}$ for $2 \mathrm{hr}$ from $\left(9.490 \times 10^{-3} \mathrm{~mm} / \mathrm{y}\right)$ to $\left(1.309 \times 10^{-3} \mathrm{~mm} / \mathrm{y}\right)$, while the corrosion resistance of AA6061 aircraft aluminum alloy decreases after solution treatment at $530^{\circ} \mathrm{C}$ for $2 \mathrm{hr}$ from $\left(886.3 \times 10^{-3} \mathrm{~mm} / \mathrm{y}\right)$ to $\left(1.270 \times 10^{-3} \mathrm{~mm} / \mathrm{y}\right)$. Pitting corrosion was the prevalent type of corrosion for both alloys.
\end{abstract}

Keywords: corrosion rate, cyclic polarization, pitting, aluminum alloys, heat treatment.

\section{Introduction}

Aluminum is has excellent corrosion resistance and the $\mathrm{Al}$ alloys are categorized into three groups, namely: casting alloys, wrought NHT alloys, and wrought HT alloys. Solution heat treatments of the $\mathrm{Al}$ alloys provide the possibility for maximal hardening solute concentration for dissolving to the solution. Such a process is often performed through heating alloy to the temperature where there is a single, solid phase. By performing such a process, the atoms of the solute which have been, at first, a portion of a 2 phase solid solution are dissolved to solution and produced a single phase. As soon as the alloy is heated to the suggested temperature of solutionizing, it will be quenched at a fast rate in a way that the atoms of the solute have no sufficient time for precipitating out of that solution. Due to the quenching, a supersaturated solution is formed between the Al matrix and the solute [1-2].In heat treatment of the solution, this alloy has been heated up to the temperature which is sufficiently high for putting soluble alloying elements into the solution. Post held at the treating temperature of the solution for sufficient time for the diffusion of the atoms of solute to the matrix of the solvent to take place, it's quenched to a lower degree of the temperature (for example, room temperature) for keeping the elements of alloying trapped within the solution. Throughout the aging, the elements of the alloying are trapped in the precipitate of the solution for forming an even distribution of highly fine particles. Some of the alloys of $\mathrm{Al}$ are hardened at room temperature in a few days in a process which is referred to as natural aging whereas others will be aged artificially through the heating to the intermediate temperatures [3].

*Corresponding Author: ebma003@uomustansiriyah.edu.iq 
Due to the creation of a barrier oxide film that is tightly bound to its surface (passive layer) and that, if damaged, instantly reforms in most conditions, relatively pure aluminum and its alloys have good corrosion resistance [4].In near-neutral solutions of most non-halide salts, this protective oxide layer is particularly stable, resulting in excellent pitting resistance. However, in open air solutions containing halide ions, with chlorine being the most common, aluminum is susceptible to pitting corrosion. This process occurs, because in the presence of oxygen, the metal is readily polarized to the pitting potential, and because the chlorides contribute to the formation of soluble chlorinated aluminum oxide (Hydro) which interferes with the formation of a stable oxide on the aluminum surface. When aluminum is present in either solid solution or in particles between metals, aluminum and its alloys oxidize easily [5]. 2000, 6000, are widely used in airframes [6].2024 alloy plates are known for their excellent fracture toughness and fatigue crack propagation characteristics, and good machinery, high strength, high fatigue strength, and corrosion resistance. For aerospace applications, they often have a higher damage tolerance and long-term durability. (N. Khatami et al.) [7] Studied the used precipitation hardening is a method of strength aging and solution that is commonly used in the T6 state. Improves the strength of the 2024 aluminum alloy, which is commonly used in aircraft usage. Pure Boron oxide $\left(\mathrm{B}_{2} \mathrm{O}_{3}\right)$ was used to add Boron to 2024AA, and alloying was completed, with the role of Boron (B) in shortening the aging time in mind. In comparison to alloys lacking Boron, good results in the Boron effect on this alloy's quench were obtained by measuring mechanical properties and microstructure observations. The findings revealed that using this component in the mix increases the hardness and tensile strength of the material during the aging process. After one hour of natural aging, the alloy's hardness increased from $73 \mathrm{HB}$ to $93 \mathrm{HB}$, and after one hour of artificial aging at $110^{\circ} \mathrm{C}$, the alloy's hardness increased from $134 \mathrm{HB}$ to $93 \mathrm{HB}$. The hardness difference is due to better precipitate distribution. (Shatha M. Rajaa et al.)[8] Studied the artificial aging and solution heat treatment effect on the Al 6061-T6 alloy's hardness and tensile strength (mechanical properties). Following the ASTM 176000 recommendations, several aluminum 6061-T6 alloy specimens were prepared for this investigation. Before being water quenched, the prepared specimens were heated at $500^{\circ} \mathrm{C}$ for one hr. The artificial aging procedure was conducted at $190^{\circ} \mathrm{C}$ for one, 2, 3, and $4 \mathrm{hrs}$. Before cooling slowly in there. Several mechanical and characterization studies, including an investigation into their microstructure, tensile strength, hardness, and pattern of XRD, were applied on the treated specimens. From the findings, the hardness and strength of the specimens were generally improved, even as the best features were obtained after 2 hours, of the artificial aging. (I M Astika, et al.) [9] Studied the artificial aging of the aluminum alloys type 2024 T3 was done in 2 steps: the solution heat treatment at $500^{\circ} \mathrm{C}$ for one hour and the artificial aging at $180^{\circ} \mathrm{C}$ for 2, 4, and 6 hours. According to findings of the study, the toughness of the aluminum type 2024 T3 increases as the aging period increases. The microstructure was becoming smoother, indicating that the precipitation hardening process was proceeding smoothly. The 6061 aluminum alloys has a density of $2.7 \mathrm{~g} / \mathrm{cm} 3$. AA 6061 is an alloy that can be heat treated and is easy to form and its resistance to corrosion is excellent and also weldable [10]. It is commonly used in lightweight aircraft, especially homemade airplanes. AA 6061 is very light and strong to a certain degree, which makes it ideal for use in the fuselage and wings. Corrosion 
potential, corrosion rate, metal susceptibility to corrosion and electrolyte concentration limits are all details that are detected by means of cyclic potentiodynamic polarization technique and this technique is a non-destructive test. The technique is based on the assumption that predictions of metal its behavior in an atmosphere can be made that by pushing a material to out of its steady-state condition and controlling how it reacts to the force as the force is extracted at a constant rate and the system is reversed to its steady-state condition. The applied potential is the force, which is increased at a constant, though slow, rate using a potentiostat. This rate is known as the polarization scan rate and it is an experimental parameter. Choosing the appropriate scan rate is very important, especially in a complex system. Otherwise, the result doesn't reflect the corrosion activity, and the result of the scan and polarization may be incorrect [11].

\section{Experimental Procedure:}

\subsection{Aluminum Alloys}

The materials used in the present work are aircraft aluminum alloys grade (2024 and 6061). The chemical compositions of these alloys were analyzed by using spectromax and the results are listed in "Table 1". This study was conducted at $0.5 \mathrm{M} \mathrm{HCl}$. The method of water jet was used to cut the plate to fit sample holder dimensions. The specimen's samples are disc shape with $(\phi 25 \times 2 \mathrm{~mm})$.

\subsection{Acid Media}

To investigate the effect of solution treatment on the corrosion behavior of both 2024 and 6061 aircraft aluminum alloys, $0.5 \mathrm{M} \mathrm{HCl}$ was used as the corrosive media in this analysis. The work was completed at room temperature, (25 $\left.{ }^{\circ} \mathrm{C}\right)$.

\subsection{Heat Treatment}

The effect of heat treatment on the corrosion resistance of both 2024 and 6061 aircraft aluminum alloys was investigated. The samples were quenched in distilled water after being heated in the lab furnace for 2 hours at $530{ }^{\circ} \mathrm{C}$ for AA 6061 and $495{ }^{\circ} \mathrm{C}$ for AA 2024. Both alloys are aged for 1 hour and 2 hour at temperatures of $\left(150,200,250\right.$, and $\left.300{ }^{\circ} \mathrm{C}\right)$.

\subsection{Corrosion Test}

The polarization cycle test show in "Fig.1" had been utilized to study the corrosion behavior of AA2024 and AA6061 aircraft aluminum alloys before and after heat treatment.

Before these tests, all samples were grinding using emery papers with different grades (300, 500,1000 , and 2000) and then polished by using alumina solution $(5 \mu)$ with a rotation speed of $250 \mathrm{rpm}$ till all the scratches were removed from the surface. The samples were then washed by using water Samples with $0.78 \mathrm{~mm}^{2}$ surface area were exposed to $0.5 \mathrm{M} \mathrm{HCl}$ media before and after solution treatment. The experimental work was carried out in three-electrode corrosion cell, 2024 and 6061 aluminum alloys are working electrode, graphite counter electrode, and calomel reference electrode shown in "Fig. 2".

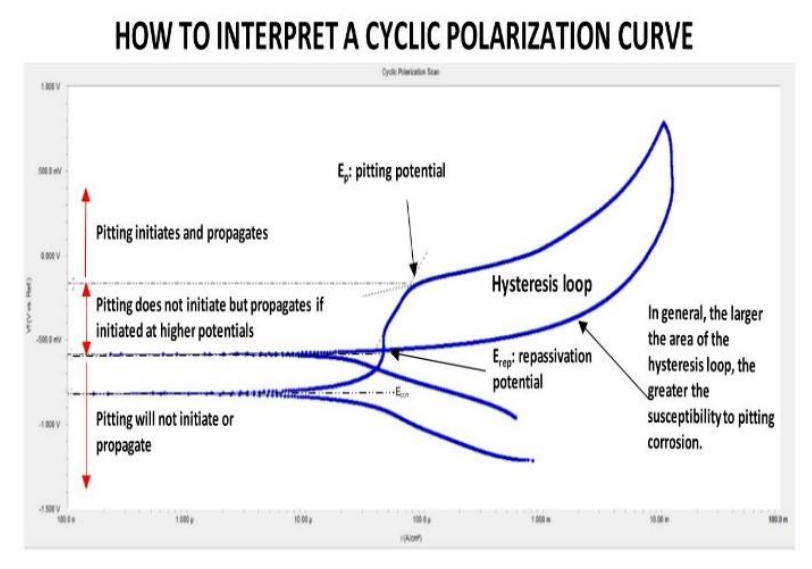

Figure 1. Interpret a cyclic 
Table 1. Chemical Analysis of the Aircraft Aluminum Alloys

\begin{tabular}{lccccccccccc}
\hline Alloy & $\mathrm{Si} \%$ & $\mathrm{Fe} \%$ & $\mathrm{Cu} \%$ & $\mathrm{Mn} \%$ & $\mathrm{Mg} \%$ & $\mathrm{Cr} \%$ & $\mathrm{Ni} \%$ & $\mathrm{Ti} \%$ & $\mathrm{Zn} \%$ & $\mathrm{~Pb} \%$ & $\mathrm{Al} \%$ \\
2024 & 0.0501 & 0.178 & 4.70 & 0.515 & 1.46 & 0.0082 & 0.0093 & 0.0240 & 0.209 & 0.0073 & 92.8 \\
& & & & & & & & & & & \\
6061 & 0.596 & 0.533 & 0.257 & 0.124 & 0.990 & 0.121 & 0.0098 & 0.132 & 0.0269 & 0.0124 & 97.2
\end{tabular}

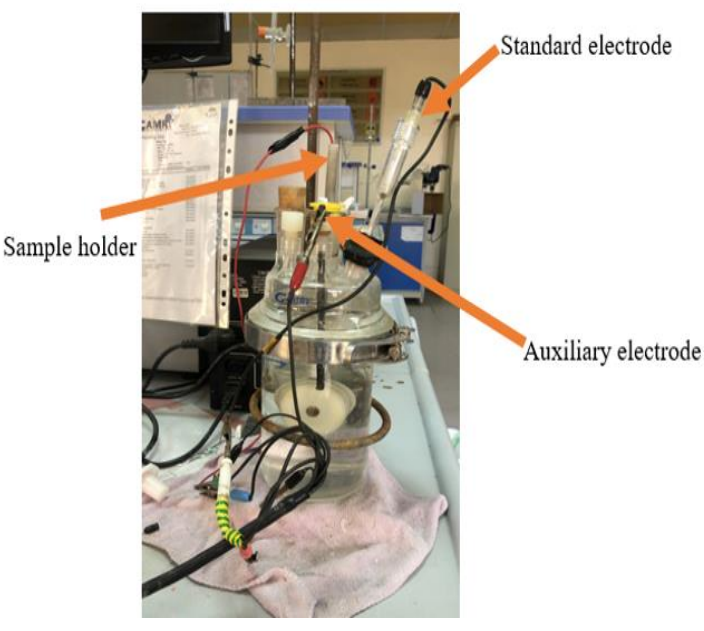

Figure 2. Electrode corrosion cell

\subsection{Optical Microscope}

In this study, optical microscopes (400X) have been used to identify the microstructure of 2024 and 6061 aircraft aluminum alloys and the type of corrosion that occurs in these alloys before and after solution treatment.

\section{Results and Dissections}

\subsection{Optical Microscopy}

"Fig. 3", and "Fig. 4", this is the microscopic structure of the 2024 and 6061 alloys, where the regions representing the alpha phase are the basis for the alloys, while the crystal boundaries appear faint and weak, a condition that is difficult to show with the used display solutions. As for the precipitated phases, they represent the phases of the metal compounds that were recorded by X-ray diffraction (After heat treatments, $\mathrm{AL}_{2} \mathrm{Cu}$ and $\mathrm{Al}_{2} \mathrm{CuMg}$ phase formed in 2024 AA while after heat treatments, $\mathrm{Mg}_{2} \mathrm{Si}$ phase formed in $6061 \mathrm{AA}$ ).
"Fig.3" shows the microstructure of both alloys before and after heat treatment and before corrosion, from this figure the microstructure of solution treatment specimens has a larger second precipitate phase than before.

"Fig.4" shows the microstructures of 2024 and 6061 alloys before and after solution treatment and after corrosion. The microstructure of solution treatment specimen higher amount of second precipitate phase than before. The difference in the microstructure of these alloys is not very large, but the alloying elements in 2024 alloy are higher than 6061. These alloying elements will affect the mechanical properties after heat treatment more than their effect on the microstructure of 6061, and this may result in fine grains. The reason for the corrosion increasing was is due to the high percentage of chloride.

"Fig.5" shows the Phases obtain from the XRD test for 2024 and 6061 before and after heat treatment. The xrd test show the precipitate particle for AA2024 and 6061AA alloy solution treated .In $2024 \mathrm{AA}$ and 6061AA alloy as received the type of precipitate particle is $\mathrm{AL}$ .For as-received samples of AA2024 alloy, the maximum value of intensity was 100 at the position of $2 \theta=38.5$, while for AA6061 alloys maximum value of relative intensity was 100 at the position of 44.84. These peaks are considered as major peaks while the other peaks with low intensity are considered as the minor peak. After heat treatments, $\mathrm{AL}_{2} \mathrm{Cu}$ and $\mathrm{Al}_{2} \mathrm{CuMg}$ phase formed in 2024 AA while after heat treatments, 
$\mathrm{Mg}_{2} \mathrm{Si}$ phase formed in $6061 \mathrm{AA}$. For artificial aging for 2024AA the maximum value of intensity was 100 at a position of $2 \theta=65.16$ for $2024,250{ }^{\circ} \mathrm{C}, 1 \mathrm{~h}$, corrosion in $0.5 \mathrm{M} \mathrm{HCl}$.for AA6061 the maximum value of intensity was 100 at the position of $2 \theta=44.72$ for $6061,200^{\circ} \mathrm{C}$, $2 \mathrm{~h}$, corrosion in $0.5 \mathrm{M} \mathrm{HCl}$.

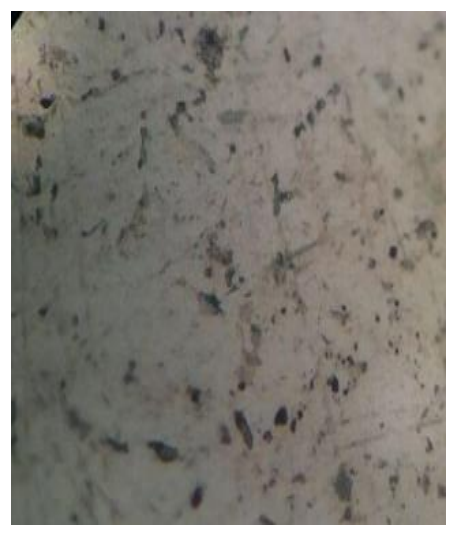

a)2024 as received

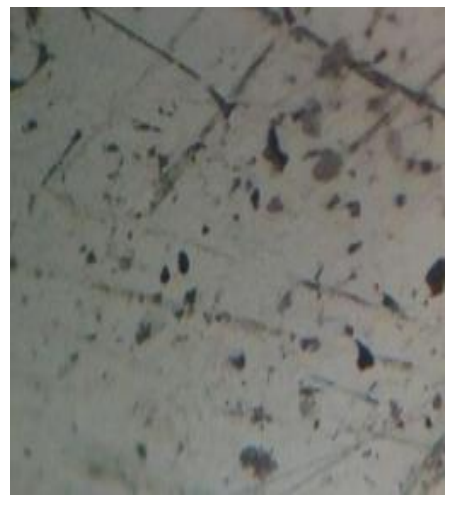

C) $2024,250{ }^{\circ} \mathrm{C}, 1 \mathrm{~h}$

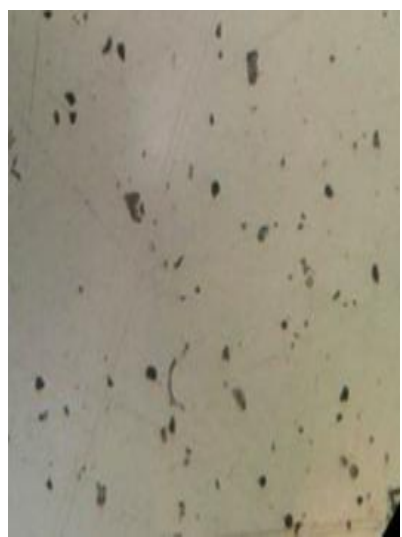

b)6061as received

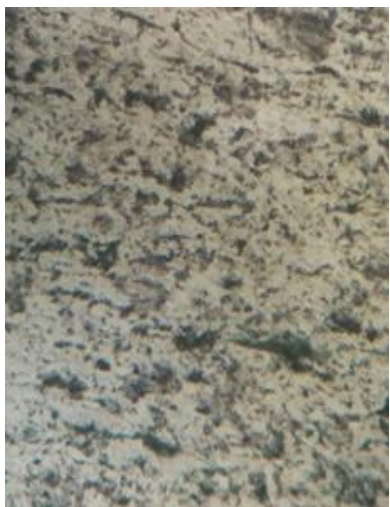

d) $6061,200{ }^{\circ} \mathrm{C}, 2 \mathrm{~h}$
Figure 3. Optical micrograph with (40x) for 2024 and 6061 before and after heat treatment and before corrosion a) 2024 standard; b) 6061 standard; c) 2024 when aging at $250{ }^{\circ} \mathrm{C}$ for $1 \mathrm{~h}$; d) 6061 when aging at $200{ }^{\circ} \mathrm{C}$ for $2 \mathrm{~h}$.

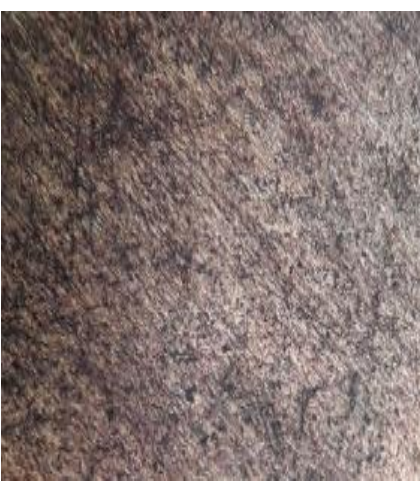

a)2024 as received

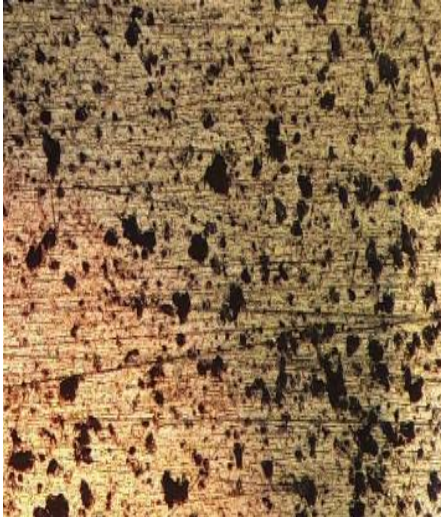

c) $2024,250{ }^{\circ} \mathrm{C}, 1 \mathrm{~h}$

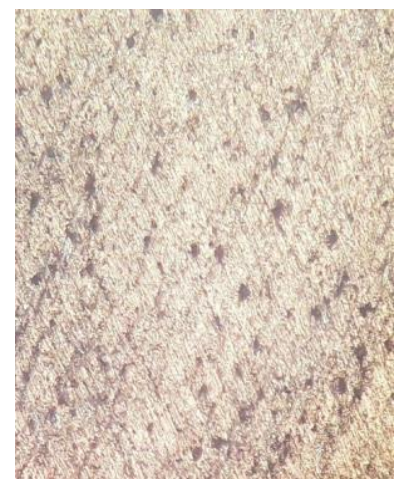

b)6061 as received

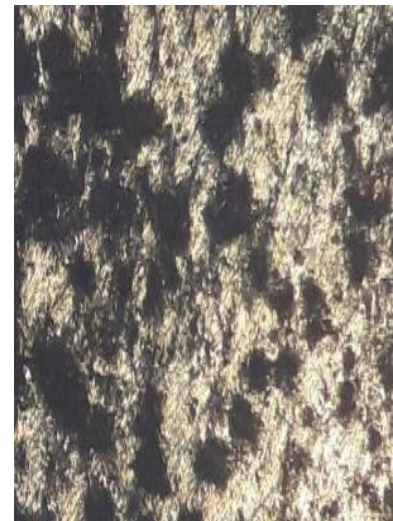

d) $6061,200{ }^{\circ} \mathrm{C}, 2 \mathrm{~h}$

Figure 4. Optical micrograph with (40x) for 2024 and 6061 before and after heat treatment and after corrosion a) 2024 standard; b) 6061 standard; c) 2024 when aging at

$250{ }^{\circ} \mathrm{C}$ for $1 \mathrm{~h}$; d) 6061 when aging at $200{ }^{\circ} \mathrm{C}$ for $2 \mathrm{~h}$

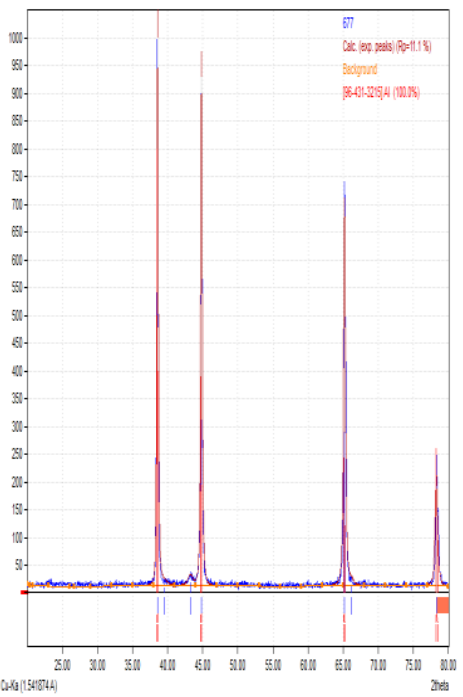

a)2024 as received

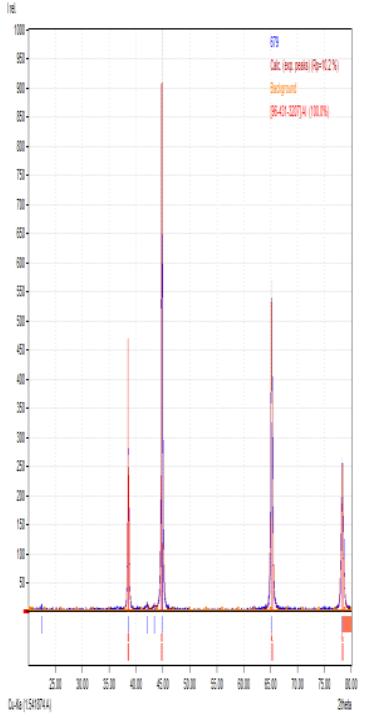

b)6061 as received 


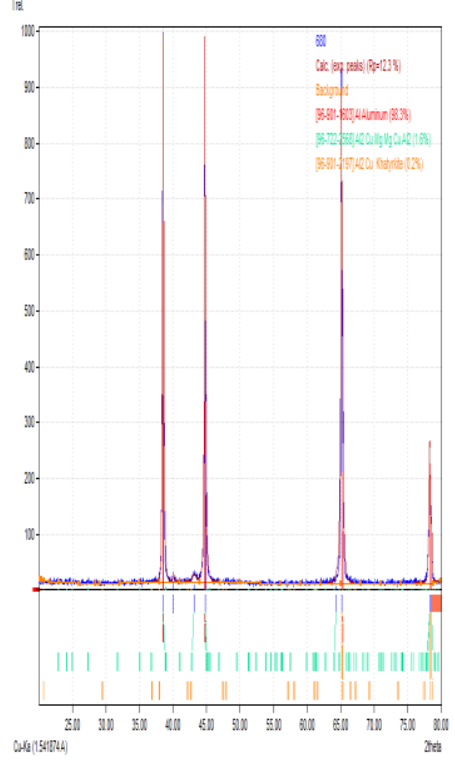

c) $2024,250^{\circ} \mathrm{C}, 1 \mathrm{~h}$

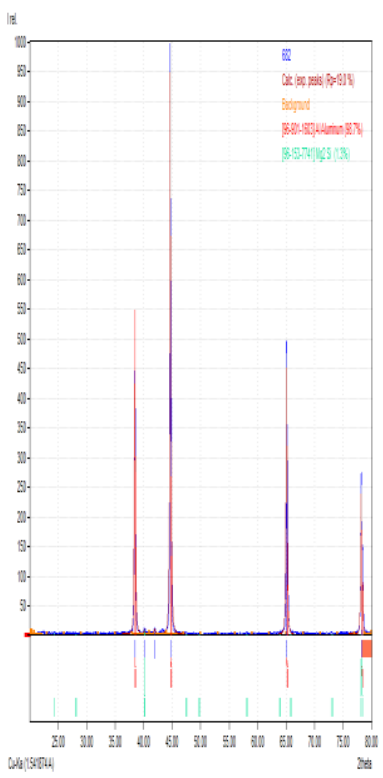

d) $6061,200{ }^{\circ} \mathrm{C}, 2 \mathrm{~h}$
Figure 5. Phases obtain from XRD test for 2024 and 6061 before and after heat treatment a) 2024 standard ; b) 6061 standard ; c) 2024 when aging at $250{ }^{\circ} \mathrm{C}$ for $1 \mathrm{~h}$; d) 6061 when aging at $200{ }^{\circ} \mathrm{C}$ for $2 \mathrm{~h}$.

3.2. Effect of Solution Treatment on the Corrosion Resistance of 2024 and 6061 Aircraft Aluminum Alloys

“" "Fig. 6", "Fig. 7, Fig. 8 and Fig. 9", represent the typical polarization curve of both 2024 and 6061 aircraft aluminum alloys in $0.5 \mathrm{M} \mathrm{HCl}$ at a temperature of $25^{\circ} \mathrm{C}$ as received samples and of $530{ }^{\circ} \mathrm{C}$ for $2 \mathrm{~h}$ for AA 6061 , and $495{ }^{\circ} \mathrm{C}$ for $2 \mathrm{~h}$ for AA 2024. The potential of corrosion ( $\left.E_{\text {corr }}\right)$ and corrosion rate of these alloys are listed in "Table 2 and Table 3"

The behavior of the curves that were recorded in the potentiodynamic is this behavior, and the state of the behavior was shown in terms of the pitting-corrosion potential and the re-passivation potential, if present or not, according to each curve. From this figure and table, it is clear that 6061 has higher corrosion resistance than 2024; this difference in the corrosion resistance of these alloys is the result of the difference in the characteristics of particles of these alloys. After solution treatment of $530{ }^{\circ} \mathrm{C}$ for $2 \mathrm{~h}$ for $\mathrm{AA}$
6061 , and $495{ }^{\circ} \mathrm{C}$ for $2 \mathrm{~h}$ for AA 2024 it had been observed that $\left(\mathrm{E}_{\text {corr }}\right)$ shift to more negative value and the corrosion rate increase and since, therefore 2024 alloy, corrosion resistance will decrease when subjected to solution treatment and 6061 alloys, corrosion resistance will increase when subjected to solution treatment.

In "Fig. 6", and "fig. (7-a, b, c, d)" are showing the Potentiodynamic polarization curves for AA2024 before and after heat treatment in 0.5 $\mathrm{M} \mathrm{HCl}$ from these figures show that the 2024 alloy as received is less affected by pitting corrosion and gets re-passivation potential $\left(\mathrm{E}_{\mathrm{rep}}\right)$ means to have high resistance to corrosion conditions, while the 2024 alloy after heat treatment is more prone to pitting corrosion and there is no re-passivation potential $\left(\mathrm{E}_{\mathrm{rep}}\right)$ and thus it is constantly and dangerously decaying. Due to the presence of the chloride ion, this accelerates pitting corrosion.

In "Fig. 8",is show the Potentiodynamic polarization curves for AA6061 before heat treatment in $0.5 \mathrm{M} \mathrm{HCl}$ from this figure showed the 6061 alloys as received are more affected by pitting corrosion and gets no re-passivation potential $\left(\mathrm{E}_{\mathrm{rep}}\right)$ means to have a low resistance to corrosion conditions. Due to the presence of the chloride ion, this accelerates pitting corrosion.

In "Fig. (9-a, b, c, d)" are show the Potentiodynamic polarization curves after heat treatment for AA6061 with aging temperatures $\left(150,200,250\right.$, and $\left.300{ }^{\circ} \mathrm{C}\right)$ for $1,2 \mathrm{hr}$. in 0.5 $\mathrm{M} \mathrm{HCl}$ from this figures showed the 6061 alloys with aging $1 \mathrm{hr}$ is less affected by pitting corrosion and gets re-passivation potential ( $\left.\mathrm{E}_{\mathrm{rep}}\right)$ means to have high resistance to corrosion conditions. And these figures showed the 6061alloy with aging $2 \mathrm{hr}$. in $0.5 \mathrm{HCl}$ is more affected by pitting corrosion and gets no repassivation potential $\left(\mathrm{E}_{\mathrm{rep}}\right)$ means to have a low 
resistance to corrosion conditions. Except for the alloy $6061,200{ }^{\circ} \mathrm{C}, 2 \mathrm{~h}$ is less prone to pitting corrosion and there is gets to re-passivation potential $\left(\mathrm{E}_{\mathrm{rep}}\right)$,Because of the protective layer that makes the metal more resistant to pitting corrosion.

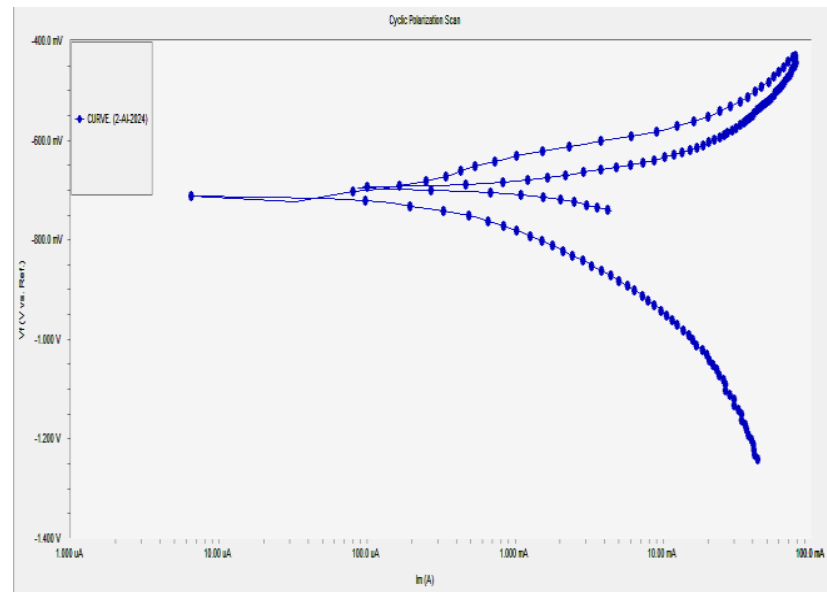

Figure (6) Curves of potentiodynamic polarization for AA2024 as received in $0.5 \mathrm{M} \mathrm{HCl}$

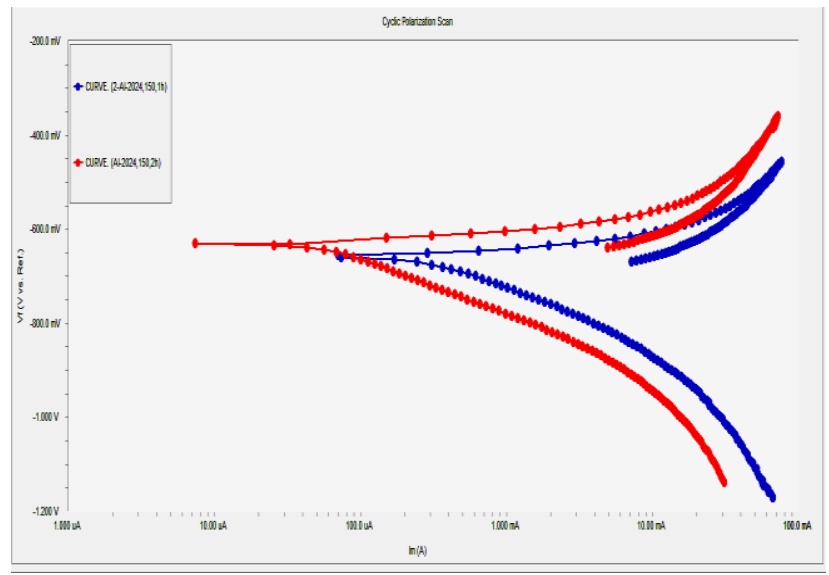

Figure (7-a) Curves of potentiodynamic polarization for AA2024 aging at $150{ }^{\circ} \mathrm{C}$ for $1,2 \mathrm{hrs}$ in $0.5 \mathrm{M} \mathrm{HCl}$

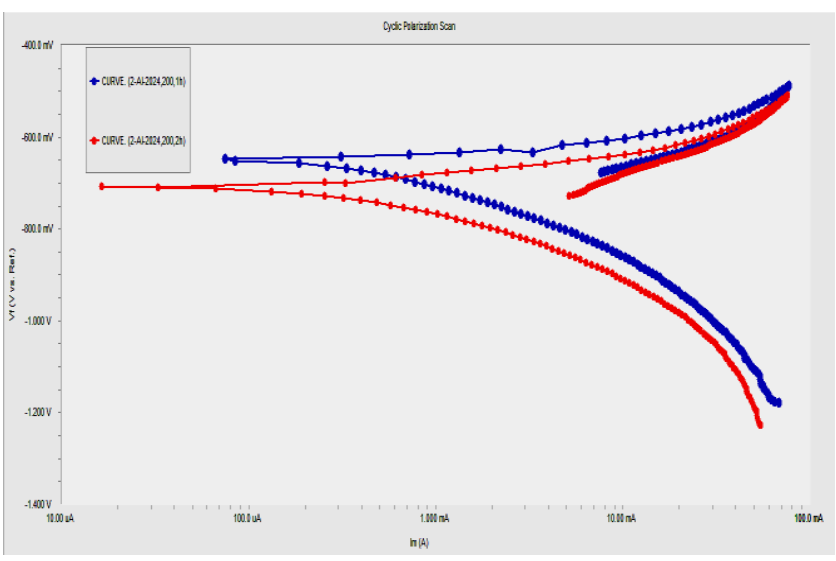

Figure (7-b) Curves of potentiodynamic polarization for AA2024 aging at $200{ }^{\circ} \mathrm{C}$ for $1,2 \mathrm{hrs}$. In $0.5 \mathrm{M} \mathrm{HCl}$

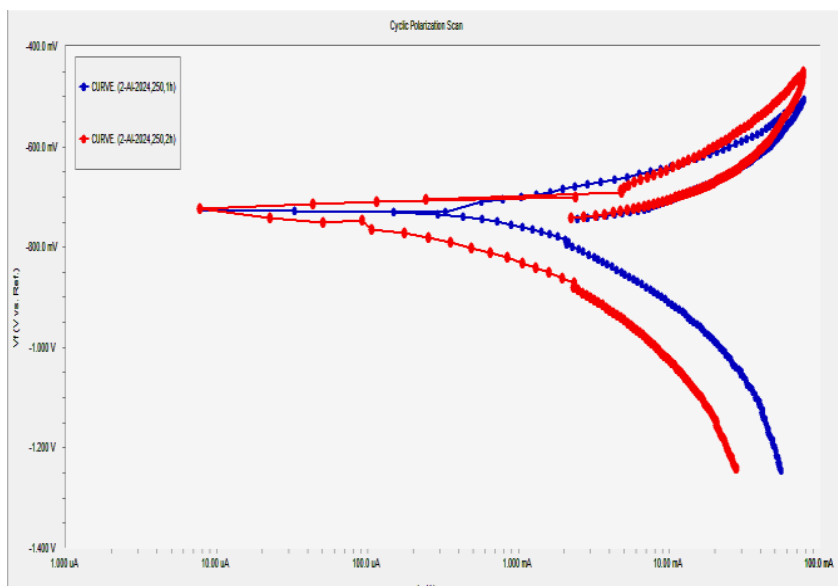

Figure (7-c) Curves of potentiodynamic polarization for AA2024 aging at $250^{\circ} \mathrm{C}$ for $1,2 \mathrm{hrs}$ in $0.5 \mathrm{M} \mathrm{HCl}$

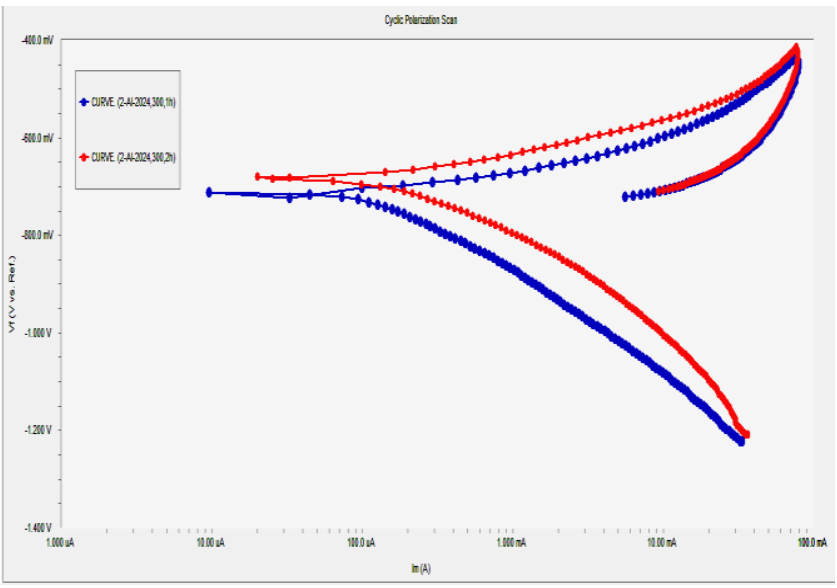

Figure (7-d) Curves of potentiodynamic polarization for AA2024 aging at $300^{\circ} \mathrm{C}$ for $1,2 \mathrm{hrs}$ in $0.5 \mathrm{M} \mathrm{HCl}$ 


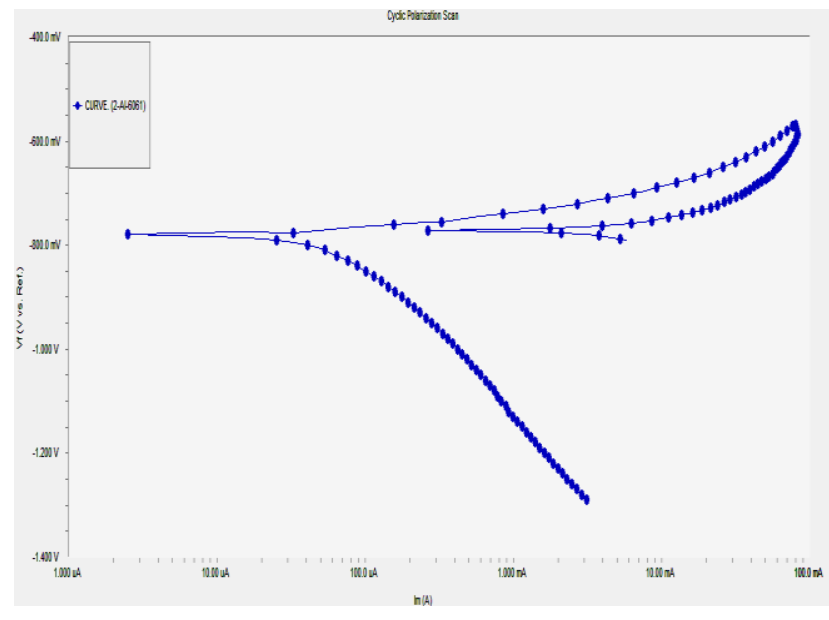

Figure (8) Curves of potentiodynamic polarization for AA6061 as received in $0.5 \mathrm{M} \mathrm{HCl}$

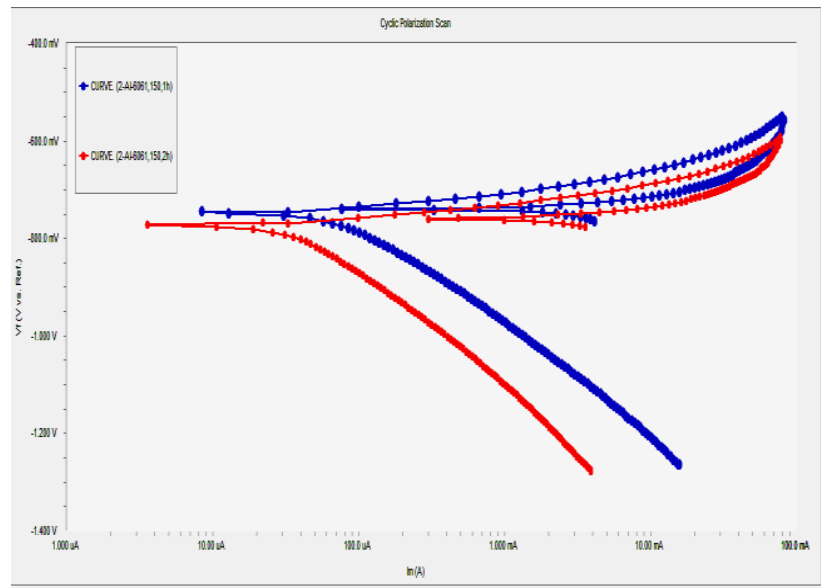

Figure (9-a) Curves of potentiodynamic polarization for AA6061 aging at $150{ }^{\circ} \mathrm{C}$ for $1,2 \mathrm{hrs}$ in $0.5 \mathrm{M} \mathrm{HCl}$

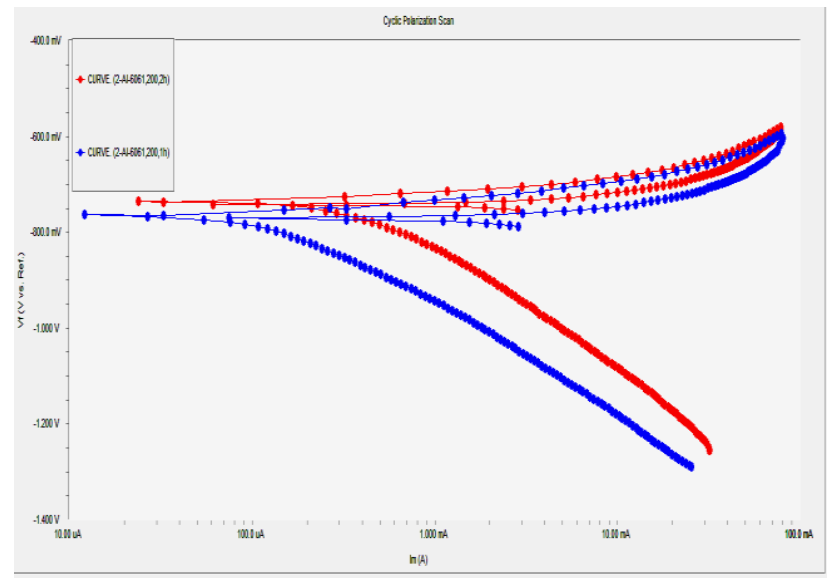

Figure (9-b) Curves of potentiodynamic polarization for AA6061 aging at $200{ }^{\circ} \mathrm{C}$ for $1,2 \mathrm{hrs}$ in $0.5 \mathrm{M} \mathrm{HCl}$

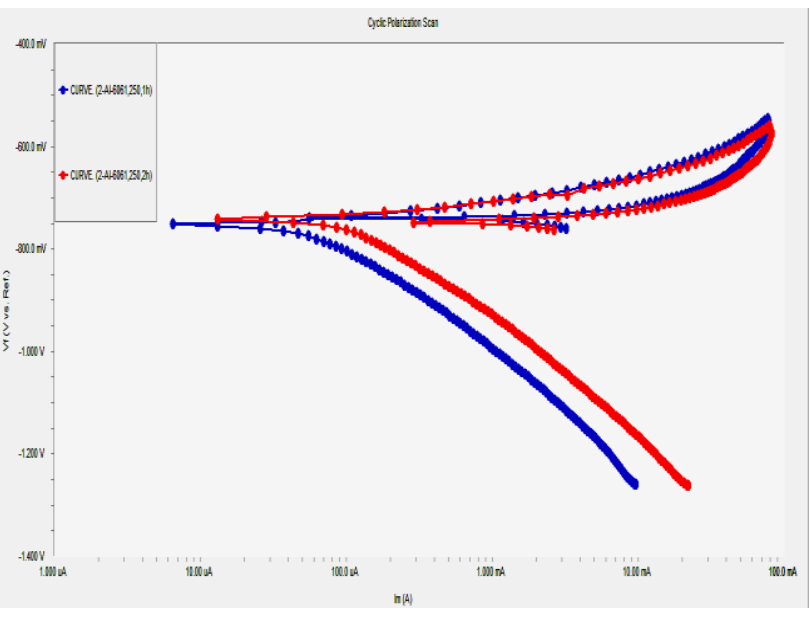

Figure (9-c) Curves of potentiodynamic polarization for 6061 aging at $250{ }^{\circ} \mathrm{C}$ for $1,2 \mathrm{hrs}$ in $0.5 \mathrm{M} \mathrm{HCl}$

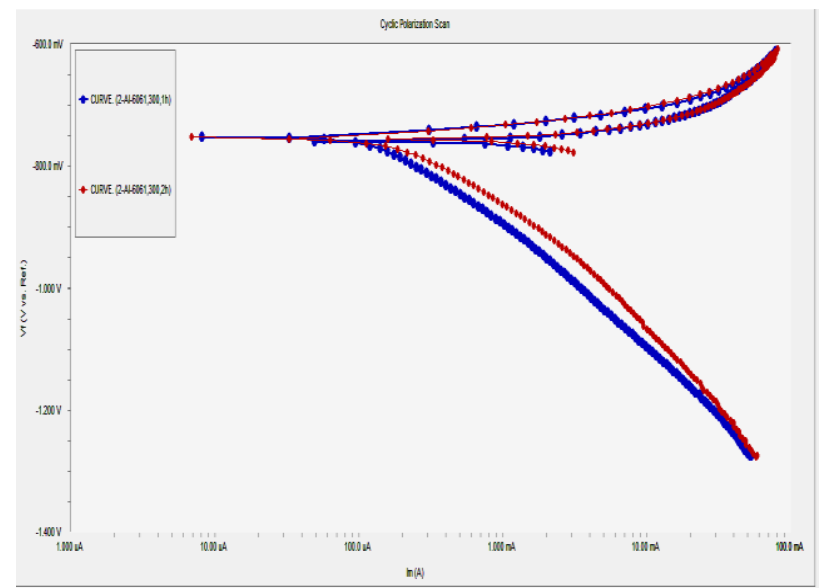

Figure (9-d) Curves of potentiodynamic polarization for 6061 aging at $300{ }^{\circ} \mathrm{C}$ for $1,2 \mathrm{hrs}$ in $0.5 \mathrm{M} \mathrm{HCl}$

Table 2. Data for AA 2024and AA 6061 in $0.5 \mathrm{M} \mathrm{HCl}$ before heat treatment

\begin{tabular}{cccccc}
\hline Alloy & $\begin{array}{c}\beta a(\mathbf{V} / \\
\text { decade })\end{array}$ & $\begin{array}{c}\beta c(\mathbf{v} / \\
\text { decade })\end{array}$ & $\begin{array}{c}\mathbf{E}_{\text {corr }} \\
(\mathbf{v})\end{array}$ & $\begin{array}{c}\mathbf{C R}(\mathbf{m m} \\
\mathbf{p y})\end{array}$ & $\begin{array}{c}\mathbf{I}_{\text {corr }} \\
(\boldsymbol{\mu A})\end{array}$ \\
\hline 2024 & $76.20 \times$ & $109.1 \times$ & -0.711 & 2.517 & 112.0 \\
& $10^{-3}$ & $10^{-3}$ & & & \\
6061 & $29.50 \times$ & $180.7 \times$ & -0.779 & $886.3 \times$ & 39.40 \\
& $10^{-3}$ & $10^{-3}$ & & $10^{-3}$ & \\
\hline
\end{tabular}


Table 3. Data for AA 2024and AA 6061 in $0.5 \mathrm{M} \mathrm{HCl}$ after heat treatment

\begin{tabular}{cccccc}
\hline Alloy & $\beta \boldsymbol{a}(\mathbf{V} /$ decade $)$ & $\beta \boldsymbol{c}(\mathbf{v} /$ decade & $\mathbf{E}_{\text {corr }}(\mathbf{V})$ & $\mathbf{C R}(\mathbf{m m p y})$ & Icorr $(\boldsymbol{\mu} \mathbf{A})$ \\
\hline $2024,150^{\circ} \mathrm{C}, 1 \mathrm{~h}$ & $32.70 \times 10^{-3}$ & $141.9 \times 10^{-3}$ & -0.657 & 7.715 & 344.0 \\
$2024,150^{\circ} \mathrm{C}, 2 \mathrm{~h}$ & $24.30 \times 10^{-3}$ & $124.2 \times 10^{-3}$ & -0.630 & 1.309 & 58.20 \\
$2024,200^{\circ} \mathrm{C}, 1 \mathrm{~h}$ & $30.90 \times 10^{-3}$ & $141.2 \times 10^{-3}$ & -0.650 & 8.427 & 374.0 \\
$2024,200^{\circ} \mathrm{C}, 2 \mathrm{~h}$ & $46.40 \times 10^{-3}$ & $121.0 \times 10^{-3}$ & -0.709 & 6.161 & 274.0 \\
$2024,250^{\circ} \mathrm{C}, 1 \mathrm{~h}$ & $61.60 \times 10^{-3}$ & $125.6 \times 10^{-3}$ & -0.725 & 9.490 & 422.0 \\
$2024,250^{\circ} \mathrm{C}, 2 \mathrm{~h}$ & $68.30 \times 10^{-3}$ & $112.6 \times 10^{-3}$ & -0.794 & 1.002 & 1.130 \\
$2024,300^{\circ} \mathrm{C}, 1 \mathrm{~h}$ & $56.10 \times 10^{-3}$ & $187.7 \times 10^{-3}$ & -0.712 & 2.693 & 120.0 \\
$2024,300^{\circ} \mathrm{C}, 2 \mathrm{~h}$ & $71.90 \times 10^{-3}$ & $186.4 \times 10^{-3}$ & -0.682 & 5.034 & 224.0 \\
$6061,150^{\circ} \mathrm{C}, 1 \mathrm{~h}$ & $30.80 \times 10^{-3}$ & $180.3 \times 10^{-3}$ & -0.746 & 1.360 & 60.40 \\
$6061,150^{\circ} \mathrm{C}, 2 \mathrm{~h}$ & $28.80 \times 10^{-3}$ & $213.2 \times 10^{-3}$ & -0.773 & $759.4 \times 10^{-3}$ & 33.70 \\
$6061,200^{\circ} \mathrm{C}, 1 \mathrm{~h}$ & $29.10 \times 10^{-3}$ & $156.9 \times 10^{-3}$ & -0.765 & 1.943 & 86.30 \\
$6061,200^{\circ} \mathrm{C}, 2 \mathrm{~h}$ & $26.20 \times 10^{-3}$ & $128.40 \times 10^{-3}$ & -0.735 & 3.698 & 164 \\
$6061,250^{\circ} \mathrm{C}, 1 \mathrm{~h}$ & $38.10 \times 10^{-3}$ & $189.2 \times 10^{-3}$ & -0.752 & 1.270 & 56.40 \\
$6061,250^{\circ} \mathrm{C}, 2 \mathrm{~h}$ & $36.10 \times 10^{-3}$ & $192.1 \times 10^{-3}$ & -0.741 & 2.318 & 103.0 \\
$6061,300^{\circ} \mathrm{C}, 1 \mathrm{~h}$ & $21.50 \times 10^{-3}$ & $144.40 \times 10^{-3}$ & -0.751 & 2.389 & 106.0 \\
$6061,300^{\circ} \mathrm{C}, 2 \mathrm{~h}$ & $24.60 \times 10^{-3}$ & $121.0 \times 10^{-3}$ & -0.752 & 2.892 & 128.0 \\
\hline
\end{tabular}

\section{Conclusions}

1. The microstructure of solution treatment specimen of AA6061 alloy solution treated at $530{ }^{\circ} \mathrm{C}$ for $2 \mathrm{hr}$. And AA2024 alloy solution treated at $495{ }^{\circ} \mathrm{C}$ for $2 \mathrm{hr}$ and aging at $\left(150,200,250\right.$ and $\left.300{ }^{\circ} \mathrm{C}\right)$ higher amount of second precipitate phase than before heat treatment.

2. The xrd test show that the precipitate particle are $\mathrm{Al}_{2} \mathrm{Cu}$ for $\mathrm{AA} 2024$ alloy solution treated, while the phase $\mathrm{Mg}_{2} \mathrm{Si}$ is the particle precipitated for alloy AA6061 solution treated.

3. 6061 alloys have better corrosion resistance than 2024 alloy in $0.5 \mathrm{M} \mathrm{HC}$, Because of the protective layer that makes the metal more resistant to pitting corrosion and completes the hysteria loop.

4. The corrosion resistance of AA6061 alloy solution treated at $530{ }^{\circ} \mathrm{C}$ for $2 \mathrm{hr}$. And AA2024 alloy solution treated at $495{ }^{\circ} \mathrm{C}$ for $2 \mathrm{hr}$ and aging at $(150,200,250$ and $300{ }^{\circ} \mathrm{C}$ ) in $0.5 \mathrm{M} \mathrm{HCl}$ decreases after heat treatment, which indicates that this heat treatment led to decrease corrosion resistance.

5. Alloy 6061 gets re-passivation potential $\left(E_{\text {rep}}\right)$ in cases 6061as received and solution treated and aged at, 200, 250, and $300{ }^{\circ} \mathrm{C}$ for $1 \mathrm{hr}$ and at aged at $200 \mathrm{C}$ for $2 \mathrm{hr}$. which means that it is more resistant to corrosion, Because of the protective layer that makes the metal more resistant to pitting corrosion .

\section{Acknowledgements}

Authors are grateful to all support given by College of Engineering, University of Mustansiriyah for academically supporting.

\section{Conflict of Interest}

The author confirms that the publication of this article causes no conflicts interests.

\section{Reference}

1. Davis. J. R., (1993)."Aluminum and Aluminum Alloys". ASM, International. 
2. Callister. W. D., (1997). "Material Science and Engineering". John Wiley and Sons, New York.

3. Campbell F.C. Ed. (2008). "Elements of Metallurgy and Engineering Alloys". ASM International.

4. Davis, J. R., (1999). "Corrosion of aluminum and aluminum alloys". ASM International.

5. Harvey, T. G., A. E. Hughes, et al. (2008). "Non-chromate de-oxidation of AA2024T3: Sodium bromate-nitric acid (20-60)." Applied Surface Science 254(11): 35623575.

6. Pantelakis Sp.G. and Alexopoulos N.D. (2008)."Assessment of the ability of conventional and advanced wrought aluminum alloys for mechanical performance in light-weight applications". Materials and Design, Vol. 29, pp. 80-91.

7. Khatami N.,MirdamadiSh., RazavizadehH., (2011)."The Boron Effect on Mechanical Properties of Aged 2024 Aluminum Alloy". 'Advanced Materials Research, Vol. 339 pp 152-156.

8. ShathaM.Rajaa,HassanA.Abdulhadi,Khair allahS.,Jabur,GhusoonR.,Mohammed.(201 8). "Aging Time Effects on the Mechanical Properties of Al 6061-T6 Alloy". 'Engineering, Technology \& Applied Science Research Vol. 8, No. 4, pp. 31133115.

9. Astika I M (2019). "Hardness improvement of aluminum alloy 2024 t3 after artificial aging treatment". Materials Science and Engineering 539.

10.Hatch. J.E. (1984). "Aluminum: Properties and Physical Metallurgy". Aluminum Association Inc. and ASM International

11. Silverman D.C. (1998). 'Tutorial on Cyclic Potentiodynamic Polarization Technique". In Corrosion/98, NACE International, San Diego, CA. 